\title{
Articulatory Variability in 24- to 36-Month-Old Typically Developing Children
}

\author{
Hee-Yun Kim ${ }^{a}$, Seunghee $\mathrm{Ha}^{\mathrm{b}}$ \\ ${ }^{a}$ Department of Speech Pathology, Graduate School, Hallym University, Chuncheon, Korea \\ ${ }^{b}$ Division of Speech Pathology and Audiology, Audiology and Speech Pathology Research Institute, Hallym University, Chuncheon, Korea
}

\author{
Correspondence: Seunghee $\mathrm{Ha}, \mathrm{PhD}$ \\ Division of Speech Pathology and Audiology, \\ Audiology and Speech Pathology Research \\ Institute, Hallym University, 1 Hallimdaehak-gil, \\ Chuncheon 24252, Korea \\ Tel: $+82-33-248-2215$ \\ Fax: +82-33-256-3420 \\ E-mail: shha@hallym.ac.kr
}

Received: April 5, 2016

Revised: May 12, 2016

Accepted: May 27, 2016

\begin{abstract}
Objectives: This study aims to investigate the articulatory variability of word and phoneme production on spontaneous utterance samples in typically developing children age 24 to 36 months. Methods: Speech samples were collected from 11 children age 24 to 30 months and 11 children age 31 to 36 months. Word variability, phoneme variability, percentage of consonants correct (PCC), and consonant inventory were measured. Eojeol was a basic unit for analysis of word variability. Both correct articulations and error productions were included for the variability analysis. Statistical analyses were conducted to investigate whether word and phoneme variability measures were different between the two age groups and if there were relationships between articulatory variability measures and PCC and consonant inventory. Results: For the children age 24 to 30 months, 51.55\% of Eojeols which were produced more than twice showed variable productions and $69 \%$ of consonants in the consonant inventory showed variability. For children age 31 to 36 months, word variability and phoneme variability were $36.45 \%$ and $52.45 \%$, respectively. Both variability measures showed significantly negative correlation with PCC and consonant inventory. Conclusion: This study suggests that 2-year-old children show progressively stable and consistent articulation patterns along with phonological acquisition. The results of this study have implications for evaluating the degree of articulatory variability in children who have inconsistent phonological disorders or childhood apraxia of speech.
\end{abstract}

Keywords: Word variability, Phoneme variability, Inconsistent phonological disorder, Twoyear-old children's phonological development, Spontaneous utterance sample analysis
조음 변이성은 초기 음운 습득 과정에서 연령이 낮은 아동에게 관찰되는 말 특징이고 연령이 증가하고 음운 습득이 진행되면서 점 진적으로 사라지는 특성이다(Sosa \& Stoel-Gammon, 2006). 변이 적인 조음 특성이 장기간 높은 비율로 두드러지게 나타나면 아동기 말실행증뿐만 아니라 비일관적 말소리 장애(Dodd, Holm, Crosbie, \& McCormack, 2005)와 같은 말소리 장애로 진단될 수 있다. Holm, Crosbi 그리고 Dodd (2007)는 말소리 습득 과정에서 일시적 으로 관찰되는 정상적인 변이성(variability)과 장애진단 표지로서 의 비일관성(inconsistency)의 특징을 구별하고 공식적으로 용어를 정의해야 할 필요성을 강조하였다. 장애진단 표지인 비일관성과 발 달적 말소리 습득 과정에서 나타나는 변이성의 특성을 구별하기 위 해서는 일반아동의 변이적인 조음 특성에 대해 자세히 살펴볼 필
요가 있다. 말소리 습득 과정에서 나타나는 변이적인 조음 특성을 살펴보면 단어 내 말소리 위치에 따라 같은 말소리가 서로 다른 형 태로 나타날 수 있고, 위 아래 입술의 움직임보다 턱 움직임의 발달 이 보다 일찍 숙달되는 것 같이 조음기관 조절과 협응상의 성숙 정 도에 따라 산출의 형태가 달라질 수 있다. 또한 심상어휘집(lexicon)에 저장되어있는 어휘에 대한 잘못된 지각과 표상으로 인해 음 운적으로 비슷한 다른 형태로 산출할 수도 있으며, 대화 중에 청자 의 피드백과 반응에 따라서 산출의 형태를 변화시켜 조음할 수도 있다. 발화가 한 낱말 산출단계에서 문장 산출로 확장됨에 따라 언 어학적 문맥이 바뀌게 되는 것 또한 단어 및 말소리가 서로 다른 형 태로 산출되는 이유가 될 수 있다. 따라서 변이성은 조음음운능력 의 발달로 인해 아동이 성인의 산출 형태로 낱말을 실현시키는 과 
정 중에 있음을 나타내는 긍정적인 신호일 수 있다(Dodd, Leahy, \& Hambly, 1989; Ferguson \& Farwell, 1975; Forrest, Elbert, \& Dinnsen, 2000; Green, Moore, \& Reilly, 2002; Grunwell, 1987; Kenney, Prather, Mooney, \& Jeruzal, 1984; Kenney \& Prather, 1986). 대조적으 로 비일관적 말소리 장애 특성을 살펴보면 목표 음소가 불규칙적 으로 많은 수의 음소로 대치되어 산출되기 때문에 오류를 예측할 수 없다. 또한 음절생략, 축약, 도치와 같은 음절 구조를 변화시키는 비발달적인 오류패턴의 산출 비율이 높다. 따라서 말명료도가 매 우 낮기 때문에 다른 말소리 장애 아동보다 어린 연령대에 언어평 가를 받게 된다(Dodd et al., 2005; Stackhouse \& Wells, 1997).

조음 변이성을 살펴본 선행연구에 따르면 초기 음운 습득 단계 인 2세 아동들의 말소리 산출에 높은 변이성이 나타났다(Dyson \& Paden, 1983; Leonard, Schwartz, Morris, \& Chapman, 1981; Sosa \& Stoel-Gammon, 2006). Leonard 등(1981)은 1세 10개월에서 2세 2 개월 일반아동 8 명을 대상으로 낱말 내 음소 변이성을 살펴보았 다. 연구 결과, 이 시기에 변이성이 나타나는 것은 자음이나 낱말 구 조와 같은 음운체계 요소들이 아직 완성되지 못했기 때문이라고 하였다. Dyson과 Paden (1983)은 2세 아동의 음운 습득 전략에 대 한 종단연구에서 18 개월에서 36 개월 사이의 아동은 성인의 모델에 최대한 도달하기 위해 극심한 변이성을 나타내는 연령대라고 보고 하였다. 또한 Sosa와 Stoel-Gammon (2006)도 1-2세 아동을 대상 으로 종단연구를 실시하였는데 낱말조합이 일어나는 시기에 변이 성이 정점에 달했다고 보고하였다. 전반적으로 많은 연구에서 초기 음운발달 시기인 2 세 무렵에 조음 측면에서 높은 변이성이 나타났 다고 하였다.

아동의 조음 변이성을 객관적으로 측정하기 위해 여러 연구자들 이 검사도구와 다양한 측정방법을 제안하였다. 먼저 단어 변이성 측정에 대한 연구로 Dodd, Zhu, Crosbie, Holm 그리고 Ozanne (2002)은 조음음운 진단평가(Diagnostic Evaluation of Articulation and Phonology, DEAP)라는 표준화된 검사도구를 개발하면 서 하위 검사항목으로 비일관성 평가를 포함시켰고 비일관성에 대 한 규준 자료를 제시하였다. 측정방법으로 구조화된 25 개의 그림 에 대한 이름대기 과제를 사용하여, 아동의 변이성 산출비율을 구 하였다. Ingram (2002)은 조음 변이성의 측정방법으로 단어 단위 변이성 비율(proportion of whole-word variation, PWV)을 제안하 였는데, 단어당 서로 다른 음운 형태로 산출된 단어의 유형수를 해 당 단어가 산출된 수로 나누어 측정한다. 예를 들어 세 번 산출된 단어의 형태가 모두 동일하면 PWV는 0 (0/3)이 되고 세 번 모두 다 른 형태로 산출되었다면 PWV는 1 (3/3)이 된다. 따라서 수치가 높 을수록 단어를 다양한 음운 형태로 산출함을 의미한다. Betz와
Stoel-Gammon (2005)은 목표단어의 오류 횟수에 대한 오류유형 의 변이성을 측정할 수 있는 조음오류 변이성(overall consistency of error types) 공식을 제안하였다. Ingram (2002)의 PWV는 목표 단어의 정조음과 조음오류를 포함한 전반적인 조음 변이성을 나타 내는 측정치이고 Betz와 Stoel-Gammon (2005)의 조음오류 변이 성은 목표단어의 조음오류만을 포함시킨 측정치이다. 음소 변이성 측정에 대한 연구를 살펴보면, Tyler, Lewis 그리고 Welch (2003)는 음소의 오류 일관성을 측정하기 위해 23 개의 음소에서 대치되어 산출된 서로 다른 음소의 총 수를 계산하는 오류 일관성 지수(Error Consistency Index, ECI)를 제시하였다. Isermann (2001)은 단 어 내 음소 위치에서 비일관적 오류 비율로 비일관적인 오류가 나 타난 음소의 총 수를 목표 음소의 총 수로 나누어 계산하는 S IC Total (percent inconsistently correct out of total number of targets by position)를 제안하였다. Iuzzini와 Forrest (2008)는 조음 또는 음운장애 아동을 대상으로 두 하위 집단을 진단 및 분류하기 위해 자음 대치 비일관성 백분율(consonant substitute inconsistency percentage, CSIP)과 비일관성 정도 백분율(inconsistency severity percentage, ISP)을 개발하였다.

단어 변이성에서 전반적인 조음 변이성을 살펴볼 수 있는 Ingram (2002)의 PWV는 아동의 자발화에서 2회 이상 산출된 단어의 총 수가 아동마다 다를 수 있기 때문에 연구자는 미리 특정 목표단어 를 선정하여 총세 번 또는 다섯 번씩 산출하도록 권고하고 있다. 따 라서 PWV를 사용하여 단어 변이성을 측정하는 것은 자발화 상황 에서 제한적이다. 음소 변이성에서 Tyler 등(2003)이 제시한 ECI와 Iuzzini와 Forrest (2008)의 ISP는 비일관적 “오류”의 정도를 살펴보 는 측정치이다. Isermann (2001)의 S IC Total은 정조음과 조음오류 를 포함하여 아동의 전반적인 변이성을 측정할 수 있으나 자발화 상황에서 변이적으로 산출되는 특정 음소가 높은 빈도로 산출될 경우 낮은 빈도로 산출된 음소보다 변이성이 상대적으로 낮게 측 정되는 문제가 있을 수 있다. 즉 음소의 산출 빈도에 따라 변이성 정 도가 영향을 받을 수 있다. 따라서 본 연구는 자발화 상황에서 조 음 변이성을 살펴보는 것이 목적이므로 음소 산출 빈도에 따라 영 향을 받지 않는, 정조음과 조음오류가 모두 포함된 전반적인 변이 성을 살펴보기 위해 Dodd 등(2002)의 측정법을 토대로 연구자들 이 단어 변이성과 음소 변이성 측정치를 고안하였다.

국내 조음 변이성 연구를 살펴보면 Hwang과 $\mathrm{Ha}$ (2012)는 2세 후반에서 4세 일반아동을 대상으로 Ingram (2002)의 방법을 사용 하여 낱말 및 문장 수준에서 조음 변이성을 측정하였다. 그 결과 연 령이 증가함에 따라 조음 변이성이 감소하였는데 특히 2세 후반과 3 세에서 여러 가지 형태의 조음오류를 보이다가 4 세에 이르면 보다 
안정된 조음능력을 갖게 되어 일관적인 조음 패턴이 나타났다. Park, Hwang 그리고 Park (2011)은 2세 아동을 대상으로 Ingram (2002) 이 제안한 PWV를 낱말 수준에서 살펴보았고 평균값은 40 으로 보 고하였다. 이는 특정 단어를 아동이 산출했을 때 10 번 중 4 번은 서 로 다른 유형이 산출됨을 의미하며 수치가 낮을수록 일관된 조음 패턴이 나타났다고 볼 수 있는데 특히 2세 아동들은 단어에 대한 정조음의 일관성 및 오류형태의 일관성이 낮다고 하였다. Shin과 Lee (2015)는 24-35개월의 일반아동과 말 늦은 아동의 PWV를 단 어 수준에서 측정한 결과 말 늦은 아동의 평균값은 .48 , 일반아동 의 평균값은 .37 로 나타났다. 말 늦은 아동의 높은 변이성은 일반아 동에 비해 목표단어의 산출에서 비일관된 음운 형태가 더 많이 나 타났음을 의미하며, 말 늦은 아동의 경우 표현언어의 지체와 불완 전한 음운 체계를 갖추고 있어 목표 단어를 가변적으로 산출했다 고볼수있다.

최근에 아동의 조음 변이성의 측정방법과 측정값에 대한 연구가 이루어지고 있으나 대부분의 국내 연구들은 아동에게 낱말의 산 출을 여러 번 유도하여 낱말 수준에서 변이성을 측정하였다. 아동 의 자연스러운 말소리 산출 능력을 살펴보기 위해서는 일상적인 대 화 상황인 자발화 수준에서 조음 변이성을 살펴볼 필요가 있다. 또 한 주로 단어 변이성을 중심으로 조음 변이성을 살펴보았는데 초기 음운발달 시기로 조음 측면에서 높은 변이성이 나타나는 2 세 아동 의 음소 변이성에 대한 정보를 살펴보는 연구가 필요하다(Hwang \& Ha, 2012; Kim, Choi, \& Park, 2006; Park et al., 2011; Shin \& Lee, 2015). 따라서 본 연구에서는 표현어휘가 급속하게 증가하고 낱말 조합으로 문장산출이 활발해지면서 높은 변이성이 나타난다고 보 고되는 24-36개월 아동의 자발화에서 단어 변이성과 음소 변이성 을 측정하고 2 세 전반과 2 세 후반으로 월령집단을 구분하여 차이 를 보이는지 살펴보고자 한다. 또한 단어 변이성, 음소 변이성, 자음 정확도, 자음목록수 간에 상관관계를 살펴봄으로써 조음 변이성 의 특징을 알아보고자 하였다. 이는 아동의 정상적인 조음발달 과 정에서 나타나는 변이성에 대한 이해를 넓히고 말소리 장애의 진단 적 근거자료로 사용될 수 있을 것이다.

\section{연구 방법}

\section{연구대상}

본 연구는 서울, 경기 및 강원지역에 거주하는 일반아동을 24-30 개월과 31-36개월로 구분하여 각 11 명씩 총 22명을 대상으로 실시 하였으며 선정 기준은 다음과 같다. (1) 양육자보고에 의해 발달과 관련된 인지, 신경, 정서장애 등의 의학적 진단력이 없고, (2) 한국
Table 1. Subjects' information

\begin{tabular}{lccc}
\hline Age group & $\mathrm{N}$ & Mean age & $\mathrm{SD}$ \\
\hline 24-30 months & 11 & 26.91 & 2.84 \\
$31-36$ months & 11 & 34.27 & 1.42 \\
\hline
\end{tabular}

판 맥아더-베이츠 의사소통발달 평가(Korean MacArthur-Bates Communicative Development Inventories, K M-B CDI; Pae \& Kwak, 2011)에서 표현어휘가 $10 \%$ ile 이상이며, (3) 한국판 영유아 발달선별검사(Korea Ages \& Stages Questionnaires, K-ASQ; Heo, Squires, Lee, \& Lee, 2006)에서 정상범주에 속하는 아동들을 대상 으로 하였다. 대상자 배경정보는 Table 1과 같다.

\section{자료수집}

본 연구는 아동의 가정에 방문하여 장난감(낚시놀이, 목욕놀이, 주방놀이, 자동차 등)을 사용해 부모와 검사자가 각각 15 분씩 총 30 분간 자유롭게 상호작용을 하였다. 발화의 변이성 분석을 위해 동일한 어절이 최소 2 회 이상 산출되도록 두 놀이 회기에서 부모와 검사자는 동일한 장난감을 사용하였고 아동이 같은 어절을 반복 하여 산출하지 못할 경우 “이거 뭐야?”, “다시 이야기 해볼까” 등 질문을 사용해 2회 이상 반복하여 산출할 수 있도록 유도하였다. 아동과의 놀이 상황은 캠코더(Samsung HMX-H205BD)와 음성 녹음기(Sony ICD-UX400F)로 녹화 및 녹음하였다.

\section{자료분석}

자료분석은 30 분간 아동이 산출한 발화를 기준으로 하였고 자 료전사는 녹음 자료와 비디오 자료를 바탕으로 어절단위로 끊어 최소 5 회 이상 반복하여 들은 후 한글로 음성전사하였다. 정확한 발음은 정조음으로, 생략, 대치, 첨가, 왜곡은 조음오류로 분류하였 고, 생략된 말소리는 [Ø]로 표시하고 대치된 말소리는 대치된 자음 으로 표시하였다. 왜곡의 경우에는 IPA (International Phonetic Alphabet)의 발음 구별 부호(diacritics)나 한글 음소표기를 이용하 여 최대한 구체적으로 왜곡 형태를 표기하고자 하였다. 예를 들어/ ㄷ/과/ㅈ/의 중간소리와 같은 성인의 말소리로 구분이 어려운 미성 숙된 말소리로 발음한 경우는 [ᄃ지로 표시하였다. / 시나/ㄷ/ 음 소가 구개음화되거나/리이 과도음화된 경우 [j]를 이용하여 전사 하였다(예: /사고/ $\rightarrow$ [삭ㄱㄱ], /여기도/ $\rightarrow$ [여기닥], / 고래/ $\rightarrow$ [고j H]). 환경음이 중첩되어 발화를 분별할 수 없거나 불명료하게 산출 된 어절은 *로 표시하였고 분석에서 제외하였다. 전사자료를 토대 로 자음정확도, 자음목록, 음소 변이성, 단어 변이성을 구하였다.

단어 변이성 측정을 위한 분석은 어절 단위로 이루어졌다. 어린 
연령대의 아동이 단어를 산출할 때는 음운체계나 문법형태소를 하 나씩 조합하여 산출하는 것이 아닌 단어 전체를 기본 단위로 말·언 어를 습득하기 때문에 언어를 습득하는 초기 발달 수준의 아동에 게는 통단어 분석이 적절하다(Ingram, 2002; Macken, 1978). 그러 나 우리말과 같은 교착어의 경우 아동이 문법형태소를 산출하기 시작하면 단어라는 언어학적 단위보다는 하나의 연결된 조음 움직 임으로 산출되는 어절이 조음 측면에서는 보다 더 타당한 측정 단 위이다(Hwang \& Ha, 2012; Yoon, Kim, \& Kim, 2013). 따라서 본 연구에서는 어절 단위로 발화를 기본적으로 분석하였으며 구체적 으로 Ha와 Hwang (2013)의 기준을 따랐다. 전사가 어려운 불명료 한 발화와 감탄사(와, 이야), 호응발화(응, 그래, 네, 어)는 분석에서 제외하였다. 그리고 언어학적 단위인 어절로 분리되지만 구어의 특 징으로 한 호흡에 연속적으로 조음이 나타날 수 있는 수사와 의존 명사(예: 한 개, 두 개), 본용언과 보조용언이 결합되는 경우(예: 찾 아갔어요, 닫아졌어)와 고유명사 또는 관형어가 불완전명사와 결 합되는 경우(예: 요리하는 거, 입는 거야), 부정어와 동사가 결합되 는 경우(예: 안 먹어)는 하나의 어절로 간주하였다. 따라서 측정 단 위를 보다 정확하게 기술하면 자연스러운 발화에서 하나의 덩이 (토막)로 발음되는 음운론적 단어를 기본 단위로 분석하였다(Shin $\& \mathrm{Cha}, 2003)$. 단어 변이성 측정을 위해 어절(음운론적 단어)을 기 본 단위로 선정하였기 때문에 문장 내 2회 이상 산출된 어절을 선 정하였고 서로 다른 문법형태소가 결합되는 경우(예: 벌레가, 벌레 는)는 다른 어절로 구별하여 분석하였다.

조음 변이성 측정치는 자발화 상황에서 일반아동의 정조음과 조음오류가 포함된 전반적인 변이성을 살펴보기 위해 Dodd 등(2002) 의 측정법을 토대로 연구자들이 고안한 측정치를 사용하였다.

\section{단어 변이성}

단어 변이성은 아동이 2 회 이상 산출한 목표 어절 유형수 중에 서 음성 실현이 서로 다르게 산출된 어절의 유형수의 비율로 측정 하였다. 예를 들어 대상자가 / 가제/를 /가제/, / 가제/, / 가데/로 /오리/ 를 /오디/, /오디/, /오이/로 /포도/를/포도/, /포도/로 산출하였다면 2 회 이상 산출된 어절의 유형수는 /가제/, /오리/, /포도/로 3이고 서 로 다르게 산출된 어절의 유형수가 / 가제/, /오리/로 2이므로 $67 \%$ $\left(2 / 3^{*} 100\right)$ 로 측정된다. 이는 아동이 2 회 이상 산출한 어절 중 $67 \%$ 가 서로 다른 형태로 산출되었다고 해석할 수 있다. 단어 변이성 측정 공식은 다음과 같다.

$$
\text { 단어변이성 }=\frac{2 \text { 회 이상 산출된 어절 중 서로 다르게 산출된 어절의 유형수 }}{2 \text { 회 이상 산출된 어절의 유형수 }} \times 100
$$

\section{음소 변이성}

음소 변이성은 아동의 자음목록에 있는 음소들 중 서로 다르게 산출된 음소의 유형수의 비율로 측정하였다. 서로 다르게 산출된 음소는 목표 자음의 생략, 대치, 왜곡된 형태를 의미하고, 모음 환경 에 따라 정상적으로 발생하는 음성적 변이음은 특정 음소의 다른 형태로 간주하지 않았다. 예를 들어 아동이 자발화 상황에서 자음 목록에 포함된 자음 개수가 초성 5 개(ㅂ, ㅁ, ᄂ, ㅈ, ㄹ), 종성 1 개 (ㅇ)이고 산출한 자음목록 중 초성에서/리을 /j, ㄹ, Ø/으로 / 지을 $/$ ᄃ, 지으로, 종성에서 / $/ 0 /$ 을 $/ 0, \varnothing /$ 으로 해당음소를 변이적으로 산출하였다. 이 경우 서로 다른 유형으로 산출된 음소의 유형 수는 초성 2개(ㄹ, 즈), 종성 1 개(ㅇ)이므로 음소 변이성이 $50 \%$ (3/6*100) 로 측정된다. 이는 아동의 자음 목록 중 $50 \%$ 가 변이적으로 산출되 었다고 해석할 수 있다.

$$
\text { 음소변이성 }=\frac{\text { 자음목록중서로 다르게산출된 음소의 유형 수 }}{\text { 자음목록수 }} \times 100
$$

\section{자음 정확도}

자음정확도 측정은 목표 자음에 대해서만 고려하였으며 목표 자음을 생략, 대치, 첨가, 왜곡한 오류를 모두 조음오류로 분석하였 고 바르게 산출된 자음 수를 전체 산출된 자음 수로 나눈 백분율 로 계산하였다.

\section{자음목록}

자음목록 측정은 Stoel-Gammon과 Dunn (1985)이 제안한 기 준에 의해 서로 다른 2 개 이상의 낱말에서 산출된 자음만을 자음 목록으로 포함했다. 아동이 산출하는 자음목록을 수집하는 것이 목적이므로 대치 또는 첨가 오류로 산출된 자음도 자음목록에 포 함시켰고 왜곡오류로 산출된 자음은 포함시키지 않았다. 음절 내 산출 위치를 고려하여 초성과 종성의 자음 빈도를 구한 후 총 자음 목록의 빈도를 구하였다.

\section{신뢰도}

어린 아동 발화의 음성전사를 위해 연구자와 언어병리학을 전공 하는 석사과정생과 함께 5 주간 총 14 시간 동안 2 세 아동의 영상과 음성 샘플로 듣기훈련을 실시한 후 분석을 시작하였다. 듣기훈련을 위해 수집된 아동의 발화를 어절 단위로 구분하였다. 초반에는 함 께 모여 음성전사를 하였고, 성인의 말소리로 구분이 어려운 미성 숙된 말소리가 포함된 어절은 반복적으로 듣고 구별하는 연습을 하였다. 해당 말소리에 대한 표기방법을 정하고 이후 각자 전사한 음성전사의 일치도가 $90 \%$ 이상이 될 때까지 반복해서 연습하였다. 
이후 전체 연구 대상자의 $20 \%$ 인 5 명의 자료를 임의로 선정하여 평가자 간 신뢰도와 평가자 내 신뢰도를 구하였다. 평가자 간 신뢰 도를 위해 듣기훈련에 참여한 언어병리학 석사과정생과 연구자가 독립적으로 전사하여 일치 여부를 구하였다. 신뢰도는 일치한 자 음 수를 전사된 자음의 총 수로 나눈 다음 100 을 곱하여 산출하였 고 평가자 간 신뢰도는 $90.63 \%$, 평가자 내 신뢰도는 $94.37 \%$ 였다.

\section{통계처리}

본 연구 결과의 통계처리는 SPSS Statistics ver. 21.0 (IBM, Armonk, NY, USA) 프로그램을 이용하여 분석을 실시하였다. 연령에 따른 단어 변이성과 음소 변이성의 유의한 차이를 확인하기 위해 독립표본 $t$-검정(independent sample $t$-test)을 실시하였고 자음정 확도, 자음목록수, 단어 변이성, 음소 변이성의 상관을 보기 위해 Pearson 상관분석(Pearson correlation analysis)을 실시하였다.

\section{연구 결과}

\section{연령집단 간 차이}

2세 전반과 2 세 후반의 두 연령집단을 구분하여 단어 변이성과

Table 2. Independent sample $t$-test results between the two age groups

\begin{tabular}{lccc}
\hline & $\begin{array}{c}24-30 \text { months } \\
(\mathrm{N}=11)\end{array}$ & $\begin{array}{c}31-36 \text { months } \\
(\mathrm{N}=11)\end{array}$ & $t$ \\
\hline Word variability (\%) & $51.55 \pm 10.87$ & $36.45 \pm 7.01$ & $-3.871^{* *}$ \\
Phoneme variability (\%) & $69.00 \pm 9.25$ & $52.45 \pm 8.59$ & $-4.345^{* *}$ \\
Percent of consonants correct (\%) & $68.36 \pm 7.99$ & $74.64 \pm 5.59$ & $2.133^{*}$ \\
Inventory of consonants (\%) & $20.64 \pm 2.69$ & $22.45 \pm .93$ & $2.115^{*}$ \\
\hline
\end{tabular}

Values are presented as mean \pm SD.

${ }^{*} p<.05,{ }^{* *} p<.01$.

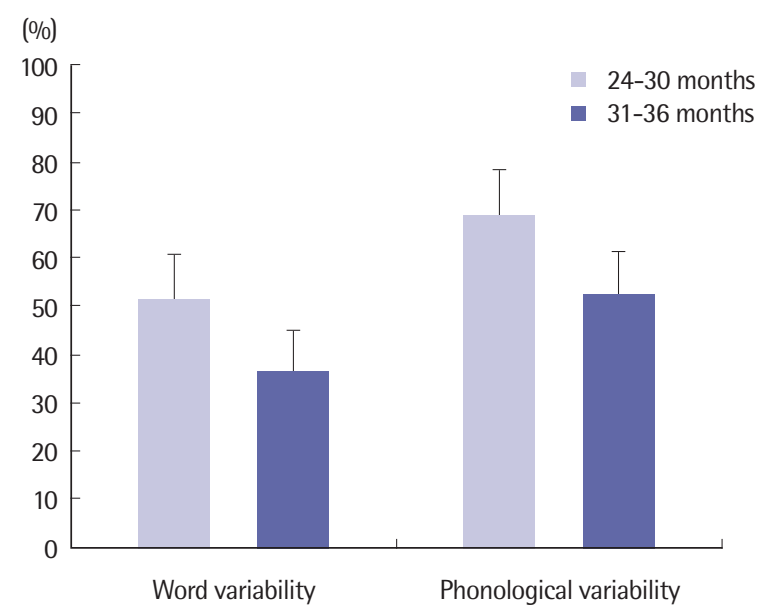

Figure 1. Mean (standard deviation) of word variability and phoneme variability at the two age groups.
음소 변이성에 차이를 보이는지 알아보기 위해 기술통계량과 $t$-검 정을 실시한 결과는 Table 2 와 Figure 1 과 같다. 30 분간 아동이 산 출한 자발화를 기준으로 단어 변이성은 아동이 2 회 이상 산출한 어절 중 2 세 전반에는 $51.55 \%, 2$ 세 후반에는 $36.45 \%$ 로 나타났다. 음소 변이성은 아동의 자음목록 중 2세 전반에는 $69 \%, 2$ 세 후반에 는 $52.45 \%$ 가 서로 다른 형태의 음소로 산출되었다. 독립표본 $t$-검정 결과 단어 변이성 $(t=-3.871, p<.01)$ 과 음소 변이성 $(t=-4.345, p<.01)$ 모두 두 집단 간 유의미한 차이가 있었는데 2세 후반집단이 2세 전 반집단에 비해 유의하게 낮은 단어 변이성과 음소 변이성을 보였다. 단어와 음소의 변이성뿐만 아니라 아동의 자발화에서 자음정확도 와 자음목록수도 측정하였다(Table 2). 변이성 측정치와 마찬가지 로 자음정확도 $(t=2.133, p<.05)$ 와자음목록수 $(t=2.115, p<.05)$ 모 두 두 월령집단 간에 유의미한 차이를 보였다.

변이성을 보이는 음소를 살펴보기 위해 먼저 Table 3에 전체 아 동 중 $70 \%$ 이상에게서 나타난 자음목록의 음소들을 제시하였다. 또한 자음목록 중 $50 \%$ 이상의 아동에게서 변이성이 나타난 음소 들은 기호 *로 표시하였다. 2 세 전반은 초성이 평균 14.64 개, 2 세 후 반은 평균 15.73 개로 마찰음 / 상 아동에게서 산출되었다. 종성 자음목록에서 2세 전반은 6 개, 2 세 후반은 7 개로 종성 파열음 /비가 추가되었다. 변이성을 보이는 음소는 초성 자음목록에서 2세 전반은 8개(ㅂ, ㄷ, ㄱ, ㄴ, ㅈ, ㅊ, ㄹ, ㅎ), 2 세 후반은 6개(ㄷ, ᄀᄀ, ᄂ, ㅈ, ㅊ, ㄹ), 종성은 2 세 전반은 6 개(ㅁ, ᄂ, ㅇ, ᄃ, ᄀ, ㄹ), 2 세 후반은 4 개(ㅁ, ㄴ, ㅇ, ㄹ)가 서로 다른 형태로 산출되었다.

\section{말소리 측정치와의 상관분석}

조음 변이성과 발달적 말소리 측정치인 자음정확도 및 자음목 록수와의 관계를 살펴보기 위해 Pearson 상관분석을 실시하였고 결과는 Table 4 와 같다. 단어 변이성과 음소 변이성 간에는 양의 상

Table 3. Phones in consonant inventories of $70 \%$ of subjects

\begin{tabular}{|c|c|c|c|}
\hline Age group & All & Initial & Final \\
\hline 24-30 months & 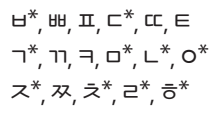 & 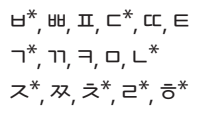 & 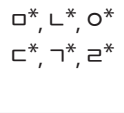 \\
\hline 31-36 months & 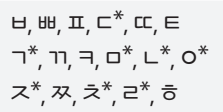 & 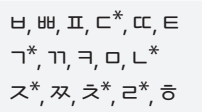 & $\begin{array}{l}\square^{*},\left\llcorner^{*}, \circ^{*}\right. \\
\forall,\left\ulcorner, \neg, \beth^{*}\right.\end{array}$ \\
\hline Total & 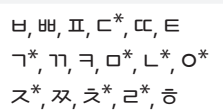 & 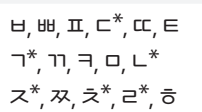 & $\begin{array}{l}\square^{*},\left\llcorner^{*}, \text { O* }^{*}\right. \\
ᄃ, \neg, \text { 己 }^{*}\end{array}$ \\
\hline
\end{tabular}

*Phonemes which $50 \%$ of children produced with variable forms in consonant inventories. 
Table 4. Pearson correlation analysis of speech measurements

\begin{tabular}{lccc}
\hline & $\begin{array}{c}\text { Word } \\
\text { variability }\end{array}$ & $\begin{array}{c}\text { Phoneme } \\
\text { variability }\end{array}$ & PCC \\
\hline Phoneme variability & $.770^{* *}$ & 1 & $-.627^{* *}$ \\
PCC & $-.773^{* *}$ & $-.627^{* *}$ & 1 \\
Inventory of consonants & $-.681^{* *}$ & $-.443^{*}$ & $.698^{* *}$ \\
\hline
\end{tabular}

$\mathrm{PCC}=$ percentage of consonants correct. ${ }^{*} p<.05,{ }^{* *} p<.01$.

관 $(r=.770, p<.01)$ 이 나타났고 자음정확도와 자음목록수 간에도 양의 상관 $(r=.698, p<.01)$ 가 나타났다. 반면 단어 변이성과 자음정 확도 $(r=-.773, p<.01)$, 자음목록수 $(r=-.681, p<.01)$ 간에는 음의 상관이 나타났다. 음소 변이성은 자음정확도 $(r=-.627, p<.01)$, 자 음목록수 $(r=-.443, p<.05)$ 간에 음의 상관이 나타났다. 즉 단어 변 이성과 음소 변이성이 낮아질수록 말소리 발달 수치인 자음정확도 와자음목록이 증가하였다.

\section{논의 및 결론}

본 연구는 자발화에 나타난 단어 변이성과 음소 변이성을 토대 로 2세 아동의 조음음운 발달 수준을 살펴보고자 하였다. 2 세 전반 과 후반으로 2 세 아동을 구분하여 두 집단 간 조음 변이성의 차이 와 조음 변이성 및 말소리 측정치 간에 상관관계를 분석하였다.

월령집단 간 단어 변이성과 음소 변이성을 살펴본 결과, 단어 변 이성은 2 세 전반 집단에서 2 회 이상 산출된 어절 중 변이적인 형태 로 산출된 어절이 $52 \%$ 정도를 차지하였으나 2세 후반 집단에서는 약 $36 \%$ 수준으로 변이적인 어절 유형수가 감소하였다. 음소 변이성 은 2 세 전반 집단에서 아동의 자음목록 중 $69 \%$ 정도였으나 2세 후 반 집단에서 $52.45 \%$ 로 감소하였다. 두 월령집단 간에 조음 변이성 에서 유의한 집단 차가 있었고 후반 집단이 전반 집단보다 더 낮은 조음 변이성을 보여 2 세 후반 집단이 전반 집단에 비해 더 일관된 조음형태로 산출하였다. 이러한 결과는 연령이 증가함에 따라 일 관된 조음능력을 나타낸다는 선행연구와 일치한 발달적 경향성을 제시하고 있다(Burt, Holm, \& Dodd, 1999; Holm, Crosbie, \& Dodd, 2005; Hwang \& Ha, 2012; Kenney \& Prather, 1986; Williams \& Stackhouse, 2000). Williams와 Stackhouse (2000)은 연령 이 증가함에 따라 조음기관의 운동 통제능력이 향상되기 때문에 일반아동의 경우 3 세에서 4 세가 되면 안정적이고 일관적인 조음패 턴으로 향상된다고 하였다. Holm 등(2005)에 따르면 아동의 안정 적이고 일관적인 조음패턴은 어휘 학습, 더 구체화된 음운표상, 말 초 청각의 변화, 조음기관의 운동능력의 변화와 관련이 있고, 연령
이 증가함에 따른 조음음운체계의 발달로 변이성이 감소한다고 보 고하였다.

Hwang과 $\mathrm{Ha}$ (2012)는 2세 후반에서 4세 일반아동을 대상으로 낱말 및 문장 수준에서 Ingram (2002)의 PWV를 사용하여 단어 변이성을 측정하였고 그 결과 변이성 측정값이 2세 후반 $46.67 \%, 3$ 세 전반은 $28.88 \%$ 로 산출되었다. 선행연구의 경우 이름대기 과제 상황에서 단어 단위의 변이성을 살펴본 연구로 아동이 산출한 특 정 단어가 얼마나 서로 다르게 산출되었는지에 대해 측정하였다. 본 연구는 자발화 수준에서 어절의 변이성을 살펴본 연구로 아동 이 2 회 이상 산출한 전체 어절 중 서로 다른 형태로 산출된 어절의 비율을 살펴보았다. 변이성 측정값이 2 세 전반은 $51.55 \%, 2$ 세 후반 $36.45 \%$ 로 두 연구에서 방법적인 차이가 있었지만 비슷한 폭으로 감소하였다. 이러한 변이성의 감소는 조음음운능력의 향상으로 보 다 일관된 조음패턴을 보이고 어휘가 급속하게 증가하고 낱말 조합 으로 문장 산출이 활발해지는 2세 아동에게 나타날 수 있는 일반 적인 특징이라고 추정할 수 있다. Dodd 등(2005)은 DEAP평가에서 25 개의 검사어휘 중 10 개 이상 $>40 \%$ ) 어휘에서 변이성이 나타났을 때 비일관적 말소리 장애로 구분하였다. 또한 Sosa와 Stoel-Gammon (2006) 연구에서도 24개월 아동의 PWV 측정값이 개인차는 있지만 50\%를 넘지 않았으며 Stoel-Gammon (2004)의 일반아동의 종단연구에서도 PWV 측정값이 2세에 $40 \%, 2$ 세 3 개월에 $34 \%, 2$ 세 6 개월에 $42 \%, 2$ 세 9 개월에 $19 \%$ 의 결과를 나타냈다. 본 연구결 과는 2세 전반에 $51.55 \%$ 로 국내외 선행연구보다 다소 높은 수치가 나타났다. 변이성 수치가 차이 나는 이유는 Hwang과 $\mathrm{Ha}$ (2012)의 연구에서는 단어수준에서 평가하였지만 본 연구는 자발화 상황에 서 발화를 분석하여 언어학적 문맥이 달랐다. 또한 대부분의 선행 연구들은 모두 Ingram (2002)의 PWV를 사용하여 본 연구와 측정 방법상의 차이가 있었다.

아동이 산출한 어절 중 변이성이 나타난 어절을 살펴보면 KM-B $\mathrm{CDI}$ (Pae \& Kwak, 2011)의 수용 및 표현어휘 목록에 포함되지 않 은, 즉 아동들에게 친숙하지 않은 단어(예: 가재, 낚싯대, 양상추)가 높은 비율을 차지하였다. 또한 음절수가 많은 단어(예: 아이스크림, 가스레인지), 아동의 자음목록 중 늦게 발달되는 말소리인 /ㅈ,ㅊ/, /리가 초성이나 종성에 포함된 어절(예: 자동차, 오렌지, 얼굴), 자 음목록에 나타나지 않은 초성 / 시 씨가 포함된 어절(예: 생선, 낚 시)에서 변이적인 패턴들이 나타났다. 이는 어휘습득 초기 단계에 서 어휘표상의 최소단위가 음소보다는 단어 또는 구이며 음운의 순서배열 방식에 대한 인지가 아직 미성숙하기 때문에(Sosa \& Stoel-Gammon, 2006) 변이적인 패턴들이 나타난 것으로 해석된 다. 또한 초성 / ㅈ,ㅊ/,/리/는 상대적으로 늦게 습득되는 자음으로 2 
세 일반아동 자음 습득기준 75\% (Sander, 1972)에 포함되지 않은 음소이다. 즉 변이성을 보인 어휘의 특징을 토대로 2 세 아동들의 조 음기관 운동능력과 어휘표상 및 음운표상이 아직 미성숙하고 불완 전하여 상대적으로 조음변이성이 높게 나타난다고 해석할 수 있다.

아동의 음소 변이성을 살펴보기 위해 자음목록을 초성과 종성 으로 나누어 분석하였을 때 2 세 전반에서 초성이 평균 14.64 개, 2 세 후반은 평균 15.73 개로 마찰음 / 시 씨를 제외한 모든 음소가 $70 \%$ 이상 아동에게서 산출되었다. 종성 자음목록에서 2 세 전반은 6 개, 2 세 후반은 7 개로 종성 파열음 / 비가 추가되었다. 자음목록 중 $50 \%$ 이상 아동에게서 변이성을 보이는 음소들을 자세히 살펴보 면, 초성 자음목록에서 변이성이 나타나는 음소에 조음 위치별 출 현빈도는 2 세 전반의 경우 성문음, 치경경구개, 치경음, 양순음, 연 구개음 순으로 높았고 조음 방법별 출현빈도는 마찰음, 유음, 파찰 음, 파열음, 비음 순으로 변이성이 높게 관찰되었다. 2 세 후반의 조 음 위치별 출현 빈도는 치경경구개음, 치경음, 연구개음 순으로 높 았고 조음 방법별로는 유음, 파찰음, 비음, 파열음 순으로 변이성이 높았다. 이는 비음, 파열음, 파찰음 순서로 발달하고 유음과 마찰음 이 늦게 발달하는(Kim \& Pae, 2005) 음소의 습득 순서와 비슷한 양상으로 변이성이 감소되는 것으로 보인다. 또한 $50 \%$ 이상 아동에 게서 변이성을 보이는 음소들 중 평음이 주로 변이적인 산출을 보 였다. 그중 / ᄀ//,/L/,/ㄷ/,/ㄹ/,/ㅂ/,/ㅎ/은 2세 전반에 더 많은 아동 에게 변이적인 형태로 나타나다가 2세 후반에서 감소하는 반면 비 교적 후기에 발달되는 음소인 / ㅈ, ㅊ/, / 리은 2세 전반보다 2세 후 반에서 더 많은 아동에게 변이적인 형태로 나타났다. / 즟/, /리 은 2 세 전반에서 아직 습득 전으로 모두 일관적으로 오류를 보이다 가 2 세 후반에는 음운 환경에 따라 정조음되거나 서로 다른 음소 로 대치되어 다양하게 산출되었다. 즉 음소의 변이적인 산출은 음 소 산출이 관찰되지 않거나, 정확하게 산출하는 완전 습득 단계가 아닌 음소 습득의 중간 단계에 놓여있는 경우 관찰되는 특징이다.

말소리 측정치 간 상관관계를 살펴본 결과, 단어 변이성과 음소 변이성에서 모두 자음정확도와 자음목록수 간에 음의 상관이 나 타났다. 이는 월령이 증가함에 따라 자음정확도와 자음목록이 향 상되어 안정된 조음능력을 갖게 되므로 보다 일관적인 조음패턴이 나타난 것으로 보인다. 변이성과 음운발달에 대한 연구들을 살펴 보면 Stoel-Gammon (2004)는 2세 아동을 대상으로 낱말 모방과 자발화 상황에서 낱말 변이성과 정확도를 측정하였을 때 21 개월에 서 $60 \%, 33$ 개월에서 $19 \%$ 로 변이성이 감소하였고 낱말정확도는 21 개월에 $7 \%$ 에서 33 개월에 $59 \%$ 로 증가하였다고 보고했다. Ertmer와 Goffman (2011)은 초성의 자음과 모음을 3 번씩 모방하게 하여 정 확도와 변이성을 측정하였고 일반아동이 높은 정확도와 낮은 변이
성을 보였다고 보고하였다. 국내연구에서는 Park 등(2011)은 2세 일반아동을 대상으로 자발화 상황에서 Ingram (2002)의 PWV를 사용하여 단어 단위 변이성을 측정하고 단어 단위 변이성과 정확 율 간 상관관계를 살펴보았고 그 결과, 변이성과 자음정확도 및 자 음목록수 간에 음의 상관을 나타냈다. 선행연구와 직접적인 비교 가 제한적이지만 정상아동의 말소리 발달 측정치가 증가함에 따라 변이성이 감소했다는 것은 본 연구 결과와 유사했다. 그러나 말소 리 발달 측정치가 증가하여도 조음 변이성이 감소되지 않았다는 연구도 있다(McCartney, 2000). McCartney (2000)는 인공와우이 식 아동과 일반아동을 대상으로 단어 단위 음운 분석을 실시해서 정확율과 변이성 간 상관을 살펴보았는데, 일반아동은 음의 상관 을 보인 반면 인공와우이식 아동은 상관이 나타나지 않았다. 이러 한 결과는 아동의 조음능력이 향상될수록 변이성이 낮아지는 것 은 일반아동에게 나타날 수 있는 특징으로 비일관적인 오류가 말 소리 장애의 주요한 증상인 아동의 경우에는 단순히 자음정확도 향상을 위한 치료가 아닌 비일관적인 오류 특성에 적합한 치료를 적용해야함을 시사한다.

본 연구는 자발화 수준에서 단어와 음소의 변이적인 산출 정도 를 살펴보고자 선행연구를 토대로 단어 변이성과 음소 변이성의 측정방법 및 측정치를 고안하였고, 2 세 아동의 조음음운발달 수준 을 살펴보았다. 그 결과 월령집단 간 통계적으로 유의한 차이를 보 여 2세 후반으로 갈수록 조음능력이 향상되어 보다 일관된 조음 형 태를 산출하게 됨을 제시하고 있다. 단어 변이성이 나타난 어절의 특징으로 친숙하지 않거나 새로 습득한 단어, 음절수가 많은 단어, 자음목록 중 늦게 발달되는 말소리가 포함된 어절이 있는데 이는 말소리 습득과정에서 나타나는 변이적인 조음 특성의 이유를 제안 하고 있다. 변이적인 산출을 보인 음소를 조음 방법별 출현빈도로 살펴보았을 때 비교적 후기에 발달되는 음소들이 2 세 전반 보다 2 세 후반에서 더 많은 아동에게 변이적인 형태로 나타났다. 이것은 2세 전반에는 아직 습득 전인 음소들로 모두 일관적인 오류를 나타 내다가 2 세 후반에 음운환경에 따라 정확하게 산출되거나 서로 다 른 음소로 대치되어 정확한 산출로 가는 전이단계에 놓여 있기 때 문으로 해석된다.

본 연구의 결과는 말소리 발달 지연 아동이나 말실행증 및 비일 관적인 조음오류를 보이는 아동의 조음 변이성 정도를 보다 객관적 으로 비교하고 평가하는 데 참고자료로 사용될 수 있다. 하지만 본 연구는 2 세 아동만을 두 월령집단으로 구분하여 연구했기 때문에 두 집단 간의 차이 즉, 발달적인 경향성만을 살펴볼 수 있다. 따라서 후속 연구에서는 1세 후반과 3-5세 아동을 포함시켜 전체적인 조 음음운발달 과정을 살펴볼 필요가 있겠다. 또한 여러 선행연구에 
서 50 개 어휘 산출 이전 시기의 아동들은 말소리 산출에서 높은 변 이성을 나타냈다고 보고하였으므로(Grunwell, 1987; Menn \& StoelGammon, 1995; Sosa \& Stoel-Gammon, 2006; Teitzel \& Ozanne, 1999) 후속 연구에서는 아동의 어휘 습득 수준에 따른 조음 변이성 의 특성을 살펴보는 것도 좋을 것이다. 또한 말소리 장애 아동의 하 위 유형을 나누는 것은 효과적인 조음치료를 실시하는 데 중요한 시사점이 있으므로 후속 연구에서는 말소리 장애 유형별로 조음 변이성의 특성을 살펴볼 필요가 있겠다.

\section{REFERENCES}

Betz, S. K., \& Stoel-Gammon, C. (2005). Measuring articulatory error consistency in children with developmental apraxia of speech. Clinical Linguistics \& Phonetics, 19, 53-66.

Burt, L., Holm, A., \& Dodd, B. (1999). Phonological awareness skills of 4-yearold British children: an assessment and developmental data. International Journal of Language \& Communication Disorders, 34, 311-335.

Dodd, B., Holm, A., Crosbie, S., \& McCormack, P. (2005). Differential diagnosis of phonological disorders. In B. Dodd (Ed.), Differential diagnosis and treatment of children with speech disorder (2nd ed., pp. 44-70). London: Whurr.

Dodd, B., Leahy, J., \& Hambly, G. (1989). Phonological disorders in children: underlying cognitive deficits. British Journal of Developmental Psychology, 7, 55-71.

Dodd, B., Zhu, H., Crosbie, S., Holm, A., \& Ozanne, A. (2002). Diagnostic evaluation of articulation and phonology (DEAP). London: Psychology Corporation.

Dyson, A. T., \& Paden, E. P. (1983). Some phonological acquisition strategies used by two-year-olds. Communication Disorders Quarterly, 7, 6-18.

Ertmer, D. J., \& Goffman, L. A. (2011). Speech production accuracy and variability in young cochlear implant recipients: comparisons with typically developing age-peers. Journal of Speech, Language, and Hearing Research, 54, 177-189.

Ferguson, C. A., \& Farwell, C. B. (1975). Words and sounds in early language acquisition. Language, 51, 419-439.

Forrest, K., Elbert, M., \& Dinnsen, D. A. (2000). The effect of substitution patterns on phonological treatment outcomes. Clinical Linguistics \& Phonetics, 14, 519-531.

Green, J. R., Moore, C. A., \& Reilly, K. J. (2002). The sequential development of jaw and lip control for speech. Journal of Speech, Language, and Hearing
Research, 45, 66-79.

Grunwell, P. (1987). Clinical phonology (2nd ed.). Baltimore, MD: Williams \& Wilkins.

Ha, S., \& Hwang, J. (2013). Speech measures from phonological analyses of spontaneous conversations in children between 18-47 months of age. Communication Sciences \& Disorders, 18, 425-434.

Heo, K. H., Squires, J., Lee, S. Y., \& Lee, J. S. (2006). K-ASQ: Korean Ages and Stages Questionnaires/a parent completed development screening tool. Seoul: Seoul Community Rehabilitation Center.

Holm, A., Crosbie, S., \& Dodd, B. (2005). Treating inconsistent speech disorders. In B. Dodd (Ed.), Differential diagnosis and treatment of children with speech disorder (2nd ed., pp. 182-201). London: Whurr.

Holm, A., Crosbie, S., \& Dodd, B. (2007). Differentiating normal variability from inconsistency in children's speech: normative data. International Journal of Language \& Communication Disorders, 42, 467-486.

Hwang, J., \& Ha, S. (2012). A study of articulatory variation in typically developing children between 2 and 4 years of age. Communication Sciences \& Disorders, 17, 403-413.

Ingram, D. (2002). The measurement of whole-word productions. Journal of Child Language, 29, 713-733.

Isermann, B. S. (2001). Variability of consistency of articulation in children with phonological disorders (Master's thesis). Ohio State University, Columbus, $\mathrm{OH}$.

Iuzzini, J., \& Forrest, K. (2008). Acoustic vowel area in phonologically disordered, CAS, and normal speech. Poster presented at the 2008 Motor Speech Conference, Monterey, CA.

Kenney, K. W., \& Prather, E. M. (1986). Articulation development in preschool children: consistency of productions. Journal of Speech, Language, and Hearing Research, 29, 29-36.

Kenney, K. W., Prather, E. M., Mooney, M. A., \& Jeruzal, N. C. (1984). Comparisons among three articulation sampling procedures with preschool children. Journal of Speech, Language, and Hearing Research, 27, 226-231.

Kim, M. J., \& Pae, S. (2005). The percentage of consonants correct and the ages of consonantal acquisition for 'Korean-Test of Articulation for Children (K-TAC)'. Korean Journal of Speech Sciences, 12, 139-149.

Kim, Y. E., Choi, S. I., \& Park, S. H. (2006). Phonological analysis of phonological disorders and normal children by whole-word approach. Korean Journal of Speech Sciences, 13, 143-155.

Leonard, L. B., Schwartz, R. G., Morris, B., \& Chapman, K. (1981). Factors influencing early lexical acquisition: lexical orientation and phonological 
composition. Child Development, 52, 882-887.

Macken, M. A. (1978). Permitted complexity in phonological development: one child's acquisition of Spanish consonants. Lingua, 44, 219-253.

McCartney, P. O. (2000). Word-initial fricative and affricate production and whole-word variability by children using cochlear implants (Master's thesis). Arizona State University, Tempe, AZ.

Menn, L., \& Stoel-Gammon, C. (1995). Phonological development. In P. Fletchr \& B. MacWhinney (Eds.), The handbook of child language (pp. 335359). Oxford: Blackwell Publishers.

Pae, S., \& Kwak, K. C. (2011). Korean MacArthur-Bates Communicative Development Inventories (KM-B CDI). Seoul: Mindpress.

Park, H. J., Hwang, H. J., \& Park, H. (2011). A study on phonological characteristics of two-years-old children by measures of whole-word. Journal of Speech-Language \& Hearing Disorders, 20, 123-135.

Sander, E. K. (1972). When are speech sounds learned? Journal of Speech and Hearing Disorders, 37, 55-63.

Shin, H. J., \& Lee, E. J. (2015). Phonological characteristics of late-talkers through phonological whole-word analysis. Communication Sciences \& Disorders, 20, 157-165.

Shin, J. Y., \& Cha, J. E. (2003). Korean speech sound system. Seoul: Hankookmunhwasa.
Sosa, A. V., \& Stoel-Gammon, C. (2006). Patterns of intra-word phonological variability during the second year of life. Journal of Child Language, 33, 3150.

Stackhouse, J., \& Wells, B. (1997). Children's speech and literacy difficulties: a psycholinguistic framework. London: Whurr.

Stoel-Gammon, C. (2004). Variability in children's speech. Paper presented at the 2004 Child Phonology Conference, Tempe, AZ.

Stoel-Gammon, C., \& Dunn, C. (1985). Normal and disordered phonology in children. Baltimore, MD: University Park Press.

Teitzel, T., \& Ozanne, A. (1999). The development of consistency of speech production. Paper presented at the 20th Annual Child Phonology Conference, Bangor, Wales.

Tyler, A. A., Lewis, K. E., \& Welch, C. M. (2003). Predictors of phonological change following intervention. American Journal of Speech-Language Pathology, 12, 289-298.

Williams, P., \& Stackhouse, J. (2000). Rate, accuracy and consistency: diadochokinetic performance of young, normally developing children. Clinical Linguistics \& Phonetics, 14, 267-293.

Yoon, M. S., Kim, S. M., \& Kim, S. J. (2013). Phonological whole-word measures of spontaneous speech in 2-4 years of age. Journal of Speech-Language \& Hearing Disorders, 22, 69-85. 


\section{국문초록}

\section{4-36개월 아동의 조음 변이성 연구}

김희윤 ${ }^{1}$ 하승희 ${ }^{2}$

'한림대학교 대학원 언어청각학과, ${ }^{2}$ 한림대학교 언어청각학부

배경 및 목적: 24-36개월 아동의 단어 변이성과 음소 변이성을 자발화 상황에서 측정하여, 아동의 월령 집단 간 차이 비교를 통해 초기 음운 발달과정 중에 나타나는 조음 변이성의 특징을 살펴보고자 하였다. 방법: 24-30개월과 31-36개월 일반아동 각 11 명씩 총 22명의 자발화를 수집하여 단어 변이성, 음소 변이성, 자음정확도, 자음목록수를 구하였다. 자발화 수준에서 단어 변이성은 어절 단위로 분석 하였고, 정조음과 조음오류를 모두 포함하여 단어 및 음소 변이성을 측정하였다. 두 월령 집단 간에 단어 변이성, 음소 변이성에서 차이 가 유의한지 분석하였고, 단어 변이성 및 음소 변이성과 자음정확도 및 자음목록수간에 상관관계를 살펴보았다. 결과: 30 분간 아동이 산출한 발화를 기준으로 단어 변이성을 살펴보면 2세 전반에는 2 회 이상 산출한 어절 중 $51.55 \%$ 가 다양한 형태로 산출되다가 2 세 후반 에는 $36.45 \%$ 로 단어 변이성이 감소하였다. 음소 변이성을 살펴보면 2 세 전반에는 아동의 자음목록 중 $69 \%$ 의 음소가 다양한 형태로 산 출되다가 2 세 후반에는 $52.45 \%$ 로 음소 변이성이 감소하였다. 단어 변이성과 음소 변이성은 모두 자음정확도와 자음목록수 간에 음의 상관관계를 나타냈다. 논의 및 결론: 2 세에 음운습득이 비약적으로 이루어지면서 안정적이고 일관된 조음 패턴을 나타낸다는 조음 특 성을 제시하고 있다. 본 연구결과는 말소리 발달지연 아동이나 비일관적인 음운 장애를 보이는 아동의 조음 변이성 정도를 보다 객관적 으로 비교하고 평가하는 데 사용될 수 있을 것이다.

핵심어: 단어 변이성, 음소 변이성, 비일관적 음운장애, 2세 음운발달, 자발화 분석

\section{참고문헌}

김민정, 배소영(2005). ‘아동용 조음검사를 이용한 연령별 자음 정확도와 우리말 자음의 습득연령. 음성과학, 12, 139-149. 김영은, 최성일, 박상희(2006). 단어단위 접근법을 이용한 음운장애 아동과 정상 아동의 음운분석·음성과학, 13, 143-155. 박희정, 황하정, 박현(2012). 단어단위 음운분석을 통한 2세 아동의 음운특성 연구. 언어치료연구, 20, 123-135.

배소영, 곽금주(2011). 한국판 맥아더-베이츠 의사소통 발달평가(K M-B CDI). 서울: 마인드프레스. 신지영, 차재은(2003). 우리말 소리의 체계: 국어 음운론 연구의 기초를 위하여. 서울: 한국문화사. 신화정, 이은주(2015). 단어단위음운분석에 의한 말 늦은 아동의 음운 특성. 언어청각장애연구, 20, 157-165. 윤미선, 김정미, 김수진(2013). 자발화 문맥에서의 단어단위 음운 평가. 언어치료연구, 22, 69-85. 하승희, 황진경(2013). 18-47개월 아동의 자발화 분석에 기초한 말소리 측정치에 관한 연구. 언어청각장애연구, 18, 425-434. 허계형, Jane Squires, 이소영, 이준석(2006). 부모작성형 유아 모니터링 체계(K-ASQ). 서울: 서울장애인종합복지관. 황진경, 하승희(2012). 2세 후반-4세 아동의 조음 변이성 연구. 언어청각장애연구, 17, 403-413. 